\title{
Spatial variation of arsenic in irrigation well water from three flood plains (Ravi, Chenab and Jhelum) of Punjab, Pakistan
}

\author{
A. Javed ${ }^{1,2}$, Z.U. Baig ${ }^{2}$, A. Farooqi ${ }^{2}$ \& A. van Geen ${ }^{3}$ \\ ${ }^{1}$ Department of Earth and Environmental Sciences, Bahria University, Islamabad, Pakistan \\ ${ }^{2}$ Environmental Geochemistry Laboratory, Department of Environmental Sciences, Faculty of Biological Sciences, \\ Quaid-i-Azam University, Islamabad, Pakistan \\ ${ }^{3}$ Lamont Doherty Earth Observatory, Columbia University, Palisades, New York, NY, USA
}

\begin{abstract}
Research work was conducted in six rice growing districts of Punjab, covering three flood plains (Ravi, Chenab and Jhelum) to investigate the geographic variations of arsenic (As) in irrigation well water. In field, irrigation well water was tested using ITS Field Kit which was later analyzed by ICP-MS at Columbia University, New York, USA. Results indicate that Ravi flood plain is different from Chenab and Jhelum Flood plain; with Ravi floodplain had a higher As concentration in irrigation wells than those from the Chenab and Jhelum Flood plain and high As wells was concentrated near the river bank. The results of this study form a strong basis for the researchers in designing detailed studies on the accumulation of As in paddy soil and possible uptake by rice.
\end{abstract}

\section{INTRODUCTION}

Arsenic (As) contamination of groundwater is a wellrecognized problem in Southeast Asia. Studies have shown that wells distribution of As is highly variable geographically and wells located near the rivers have high As levels (Berg et al., 2007). According to results of first blanket testing in Pakistan (by Abida Farooqi, USAID/HEC funded project) and in Indian side by Chander Kumar Singh (PEER funded project), As concentrations in drinking water are higher in the areas along the Ravi Flood plain whereas concentrations were low along Satluj, Chenab and Jhelum Flood plain. Therefore, in this study we hypothesized that the concentration of As in groundwater used for irrigation may also vary from one flood plain to another within a same region. Therefore, the objective of this study is the screening of irrigation wells for As that would form a basis for the researchers in designing detailed studies on the accumulation of As in paddy soil and possible uptake by rice.

\section{METHODS/EXPERIMENTAL}

\subsection{Study area and sampling}

In this study, assessment of As in irrigation wells was carried out in six rice growing districts (Narowal, Mandi Bahauddin, Gujrat, Gujranwala, Sialkot and Lahore) (Fig. 1). Mandi Bahauddin and Gujrat District lies between Jhelum and Chenab Flood plain whereas Narowal and Lahore are on Ravi Flood plain

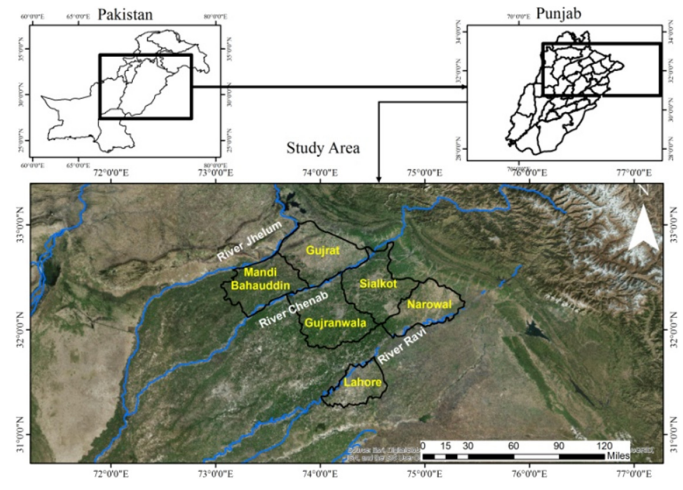

Figure 1. Map of the study area showing six rice growing districts of Punjab.

and Sailkot district lies between Ravi and Chenab flood plain.

\subsection{Analysis}

Irrigation water samples were analyzed for As using portable ITS Arsenic Econo-Quick Kit, which relies on the generation of arsine gas and visual detection on a strip impregnated with mercuric bromide and the standard reaction time was maintained at $10 \mathrm{~min}$. All the data were uploaded in survey CTO. For quality control, the standards of known quantity were prepared and tested every day before the start of work. The same well water samples were also collected for 


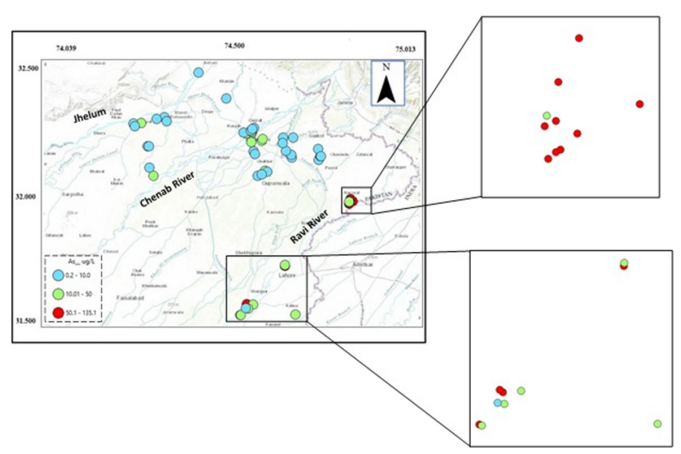

Figure 2. Spatial distribution of arsenic in irrigation wells by ICP-MS. Red dot shows the arsenic concentration $>50 \mu \mathrm{g} \mathrm{L}^{-1}$.

measurement of As at Lamont Doherty Earth Observatory (LDEO) Laboratory of Columbia University, New York, USA. Water was collected in $20 \mathrm{~mL}$ clean plastic vial and was transported to Laboratory. Water was analyzed for As by inductively coupled plasma mass spectrometry (ICP-MS) following 1:10 dilution. Before analysis, water samples were acidified with $1 \% \mathrm{HNO}_{3}$. The detection limit of the method for dissolved As is $0.1 \mu \mathrm{g} \mathrm{L}^{-1}$. Three standards were used (NIST 1640 A) with As value $8.75 \mu \mathrm{gL}^{-1}$, NIST (1643 F) with As value $56.85 \mu \mathrm{g} \mathrm{L}^{-1}$ and LDEO standard with As value $430 \mu \mathrm{g} \mathrm{L}^{-1}$ ) along with method and vial blanks. We also validated this field kit method by comparing kit As measurements with ICP-MS measurements on 60 water samples and found good co-relation $\left(\mathrm{R}^{2}=0.786\right)$ across $1-102 \mu \mathrm{gL}^{-1}$ range of concentrations.

\section{RESULTS AND DISCUSSION}

The geographic variations of As in all three flood plains is shown in Figure 2. Results indicate that Ravi flood plain is different from Chenab and Jhelum flood plain, The Ravi floodplain had a higher As concentration (ranged from 7.27 to $135 \mu \mathrm{g} \mathrm{L}^{-1}$ ) in irrigation wells than those from the Chenab (ranged from 0.2335 to $27.75 \mu \mathrm{g} \mathrm{L}^{-1}$ ) and Jhelum Flood plain (ranged from 0.2335 to $21.86 \mu \mathrm{g} \mathrm{L}^{-1}$ ). In Jhelum and Chenab flood plains none of the wells were found to have As concentration greater than $50 \mu \mathrm{g} \mathrm{L}^{-1}$ whereas in Ravi flood plain, $65 \%$ of the well exceeds $50 \mu \mathrm{g} \mathrm{L}^{-1}$ and $10 \%$ exceeds $100 \mu \mathrm{g} \mathrm{L}^{-1}$. Similar observations were also reported for groundwater As concentrations across the different geomorphological units of the Bangladesh with low concentrations of As in the higher altitudePleistocene terraces, and at high concentrations in Holocene floodplains (Ravenscroft et al., 2005). The explanation for this is that Pleistocene sediments are more highly weathered and leached of As. A study on the source of As in the Holocene/Pleistocene sediments from the Terai plain of Nepal (that stratigraphically resemble Pakistani sediments) proposed a number of complex processes which can explain the differences in As concentration between Holocene and Pleistocene sediments (Guillot et al., 2015).

In addition, spatial analysis showed that wells with higher concentrations of As were concentrated near the river bank. As the distance from River increased, the concentration of As in groundwater decreased. Stahl et al. (2016) suggests that aquifers throughout South and Southeast Asia may be vulnerable to As contamination where riverine recharge flows through recently deposited sediments. Prior to the onset of substantial groundwater pumping, As released in the pore-water of reactive riverbed sediments would have discharged into rivers and would not have influenced groundwater concentrations further inland. With largescale groundwater pumping throughout South and Southeast Asia, it is likely that many aquifers are now experiencing net inflow from nearby rivers (Berg et al., 2007). This entire phenomenon could possibly explain the geographic variation in As concentration of groundwater in the study area.

\section{CONCLUSIONS}

Results indicate that Ravi flood plain is different from Chenab and Jhelum, with Ravi floodplain had a higher As concentration in irrigation wells than those from the Chenab and Jhelum Flood plain. The results of this study form a strong basis for the researchers in designing detailed studies on the accumulation of As in paddy soil and possible uptake by rice.

\section{ACKNOWLEDGEMENTS}

The author acknowledges the Columbia University, New York, USA, Higher Education Commission (HEC), Pakistan and US-Pakistan Centers for Advanced Studies in Water, Mehran University of Engineering and Technology (MUET), Jamshoro for financial and technical support.

\section{REFERENCES}

Berg, M., Stengel, C., Pham, T.K., Pham, H.V., Sampson, M. L. \& Leng, M. 2007. Magnitude of arsenic pollution in the Mekong and Red River Deltas-Cambodia and Vietnam. Sci. Total Environ. 372(2-3): 413-425.

Guillot, S., Garçon, M., Weinman, B., Gajurel, A., Tisserand, D., France-Lanord, C., van Geen, A., Chakraborty, S., Huyghe, P., Upreti, B.N. \& Charlet, L. 2015. Origin of arsenic in Late Pleistocene to Holocene sediments in the Nawalparasi district (Terai, Nepal). Environ. Earth Sci. 74(3): 2571-2593.

Ravenscroft, P., Burgess, W.G., Ahmed, K.M., Burren, M. \& Perrin, J. 2005. Arsenic in groundwater of the Bengal Basin, Bangladesh: distribution, field relations, and hydrogeological setting. Hydrogeol. J. 13(5-6): 727-751.

Stahl, M.O., Harvey, C.F., van Geen, A., Sun, J., Thi Kim Trang, P., Mai Lan, V. \& Bostick, B.C. 2016. River bank geomorphology controls groundwater arsenic concentrations in aquifers adjacent to the Red River, Hanoi Vietnam. Water Resour. Res. 52(8): 6321-6334. 